qualifications which should he kept in mind. In children and yonng persons it rarely fails to disappenr nuder the use of sufficient doses. After middle life the drug loses some of its efficacy, and in aged people it seems to have very little effect. In these cases quinine, stimulants, and food should he relied on.

\title{
The Extinpation of Lutus.
}

Ricketrs ( $N$. Y. Afed. Journal, 1893), advises the complete extirpation of lupus either with the knife or the curette, replacing the loss of tissue, where this is considerahle, hy skin-grafting. This mode of treatment is advised not only for lupus vulgaris, hùt for lupus ery thematosus.

\section{Papillaty and Pigarentaky Dystrophy.}

Davies (Annales de Dermatologie el de Syphiligraphie; 1893, No. 7) has ohserved and studied histologically two cages of a disease of the skin nnd mucous membranes which be calls papillary and pigmentary dystrophy, it heing the sane aflection which Pollitzer and Janovgizy have descrihed under the name acantiosis nigricans. Both patients were women, aged thirty-four and forty-two years respectively, in whom, during the evolution of gastric cancer, there wis developed a modification of the integuments, characterized hy $n$ double process, papillary hypertrophy and pigmentation. The papillary hypertrophy existed nround the natural orifices, upon the hands, nbout the umbilicus, upon the tongue, and in one case upon the gums. The pigmentntion, nccompnied hy a verrucous and even papillomatous condition, was seated principally upon the neck, chiefly the nape, nnd in the articular folds, where it reached an extreme degree. Upon the trunk it assumed the form of macules similnr to plane senile warts, and in some regions, as the wrists and elhows, suall confluent plane warts. The beginning of the affection is insidiouk, but it develops and hecomes almost general in its distribution in a few months. The nffection is to be distinguished from Addison's disease, ichthyosis, senile warts, and psorospermose folliculaire vegetante, with which last it preseuts certain analogies.

The histological changes consist in an enormous increase of the thickness of the corneous layer and a moderate increase in the thickness of the rete and the stratum granulosum. The glomeruli of the sudoriparous glands were absolutely normal in appenrance.

\section{a mixed Case of Lues and Tudetculosis with Unusual Localizatios.}

Farky (Archiv $f$. Dermatolagie und Syphilis, 1893, Hof vi.) reports a case of mixed tuherculous and luetic ulcer of the prepuce. The patient, thirtyfive years old, had constitutional syphilis, having numerous scars over the hody, the result of a syphilitic eruption, and was inclined to tuherculosis. At the time of ohservation nlcers existed upon the inner surface of the prepuce, which from the history and chsracter of the lesions were diagnosticated as syphilitic, and iodide of potsssium was accordingly prescribed. This treatment, although continued for some time, was without effect, the 
ulcers extending peripherally and in depth. Under the use of suhlimate dressings healing took place, hut hardnesz and deep infiltration still remnined. Ulceration shortly agnin occurred, involving the franum, which it destroyed. A small piece of the prepuce wns now excised and examined microscopically hy Prof. Ribhert, of Zurich, who pronounced it tnherculons. Under the use of carholic ncid and sublimate dressings, together with mercurial inunctions, a permanent cure was eventually obtained.

\section{The Treatuent of Itchisa.}

Brossox ( $N$. Y. Mred. Record, 1893), in a paper upon this suhject, discusses the various measures useful in relieving this very common and often distressing symptom. These mensures are:

A. The Removal of Local Excitants. Irritating contncts of all kinds are to he scrupulously avoided. Attention is to he gisen to the underclothing, which should he of the softest material. Extreme hent or cold must be aroided, as well as sudden chnnges of temperature. As local excitants may he intra- is well as extra-cutaneous-as when dne to toxic materials conveyed to the stin hy the blood-depurative remedies, such as diuretics nod dinphoretics, are, in proper cases, to be employed.

B. Sedatives. Used internally these are less satisfactory than when applied to the skln. The hromides are often of benefit, and hypnotles, such as sulphonal, are occasionnlly needed. Two internal remedies especially worthy of mentlon are cannnhis indicn and gelsemium. Phenacetine nnd nnlipyrine nre likewlse useful. Among locel sedatives carbolic acid is the most relinble, and the nuthor recommends its employment in the following formula:

$$
\begin{aligned}
& \text { B.-Acid. carholic. . . . . . . . } \mathbf{5} \mathbf{j}-\mathbf{i j} \text {. }
\end{aligned}
$$

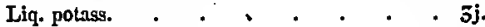

$$
\begin{aligned}
& \text { Ol. lini . . . . . . . . Jj.-M. }
\end{aligned}
$$

Sig.-Shake before using.

Sulicylic acid and salol act similarly to carbolic acid, but are less effectlve. Thymol is also useful, hut on acconat of its irritating effect is contra-indicated when the stin is sensitive. Corrosive chloride of mercury nlso possesses anti-pruritic properties. Cocnine often gives satisfactory results in localized forns of pruritus about mucous orifices and upon abraded surfaces. Water of the temperature of $100^{\circ} \mathrm{F}$. and over is likewise useful.

C. Sensory Stimulants. It is more especinlly in such forms of pruritus as are associated with hypopselsphesin [sic] that remedies of this class are indicated. Anong theso agents electricity, either as galvanism or faradism, is of henefit. Strychnine is also of value.

D. Substitutive Irritants. Menthol, which is one of the hest palliatives of itching, in the author's opinion acts, not by direct inhihition of the molecular movements of the sensory nerves, hut hy suhstituting an exaggerated temperature-sense for the perturbed sense of contact.

E. Alterations of Cutaneous Nutrition. Jnhorandi probshly helongs in this class, and is especially useful when the skin is hot nnd dry. Among the local remedies are ichthyol (i-10 per cent), tumenol (25 per cent. or pure), ocessionally tar, resorcin (3 per cent.), and benzoic acid or henzoin. The author, observing the fact that a large proportinn of remedies that allny itching are 